\title{
THE EFFECT OF PROFITABILITY, LIQUIDITY AND SOLVENCY ON CORPORATE SOCIAL RESPONSIBILITY
}

\author{
Yunita Easty Pertiwi Lolo*1, Willy Sri Yuliandhari ${ }^{2}$ \\ Telkom University, Indonesia \\ yunita.easty.ye@gmail.com¹ ${ }^{\star 1}$ willyyuliandhari@telkomuniversity.ac.id²
}

\begin{abstract}
CSR is an obligation of a company that not only provides the needs of the community but also pays attention how to maintain environmental quality positively contributing to the communities in which the company operates. Because it is a indices Sri-Kehati generally consists of companies that are already stable and have good performance. With increasing public awareness of the company's environment, it is demanded to have responsibility for operational activities carried out not only by focusing on the profits generated, howover, based on a survey conducted at the Research Center for Governance, Institutions, and National University Singapore (NUS) Business School shows lack of companies understanding of CSR practices especially in Indonesia (CNN Indonesia, 2016). The purpose of this research is to find out several factors that influence CSR practices so that the variable in this study are CSR disclosure and the independent variables are profitability (net profit margin), liquidity (current ratio) and solvency (debt to total asset). The sample of this study was 60 sample consisting of companies listed on the Sri-Kehati index in the 2015-2018 using data panel regretion with the help of Eviews 10 application with quantitative methods. The result of this study indicate that simultaneous profitability (net profit margin), liquidity (current ratio), and solvency (debt to total asset) affect CSR disclosure. Partially profitability (net profit margin), liquidity (current ratio, and solvency (debt to total asset ratio) affects the disclosure of CSR with the ability of independent variables explain the dependent variable at $66,51 \%$. The company is expected to be able to control the use of debt of a source of funding and reduce the use of expenses so that operational activities do not depend on debt.
\end{abstract}

Keywords: CSR disclosure, Profitability, Liquidity, Solvency

\section{INTRODUCTION}

Sri-Kehati is one of the indices used as a benchmark to see the movement of shares in the Indonesia Stock Exchange with was launched on June 8, 2009 by Yayasan Keanekaragaman Hayati (KEHATI) as a result of cooperation between Indonesia stock Exchange and it is the first green index in Indonesia (SWA, 2018). Because it is green index Sri-Kehati generally consist of companies that are already stable and have good performance. The selection of the Sri-kehati index as the object of research can help research to find out whether the existence of the index can increase companies in carrying out CSR activities and reveal the company's CSR activities in sustainability report in addition to looking of the maximum profit. With increasing public awareness of the environment, companies are required to have responsibility for operational activities that have been carried out not just for profit. However, based on survey conducted by the Research Center for Governance, Institution, and Organization of the National University of Singapore (NUS) Business School show the company's low understanding of CSR practices especially in Indonesia (CNN Indonesia, 2016).

Profitability is a ratio to assess the ability of a company to generate profits in a certain period (Maulani \& Mudjiyanti, 2017). According to Lukman (2018: 61) using the company's net profit margin will focus on spending efficiency and then increase the volume and 
number of sales. Liquidity is a relationship between cash and other current assets that serves as an indicator for the company to assess its ability to pay off short-term obligations when due (Maulani \& Mudjiyanti, 2017). According Kamsir (2014: 13) the most common ratio used to measure liquidity is the Current Ratio because this ratio serves to show the level of safety (margin of safety) to meet the obligations of a company. There it is necessary to compare between current assets and current liabilities, the greater the results will show the company's ability to meet its short-term obligations more quickly. Solvency is the company's ability to meet long-term obligations at maturity (Wasito, Herwiyanti, \& Kusumastati, 2016).Debt to total assets is useful to measure how the assets used can guarantee liabilities owned, besides that debt to total asset also serves to assess the extent to which debt affects the management of assets. Stakeholder Theory, according Bowern in Mardikanto (2014: 86) defines that CSR is an obligation of a company to formulate a policy and decision based on the goals and values of the community. Thus the company does not only focus on profits but still has responsibilities to various parties (stakeholders) related to the company's operational activities because the sustainability of a company is highly dependent on the support of stakeholders. CSR is an act of concern for business activities carried out on the environment, both in business activities and outside business activities (Hasnia \& Rofingatun, 2017). In addition, according to Mardikanto (2014: 132-136) the perpetrators (Munawir, 2005) CSR has many benefits that can be felt by various parties, both for companies, investors, governments, and surrounding communities. Kamsir $(2014: 196)$ is a profitability ratio that used companies for profit, this ratio can provide a measure of the level of an enterprise management effectivity shown on the income generated from sales or from investment income. Lukman (2018:61) by using the company's net profit margin will focus on spending efficiency and then increase the volume and number of sales. In this study the ratio of net profit margin is used because it can assess the net profit received based on each rupiah earned, the greater the value obtained indicates that the ability to obtain the company's profit is higher.Liquidity is a relationship between cash and other current assets that serves as an indicator for the company to assess its ability to pay off short-term obligations when due (Maulani \& Mudjiyanti, 2017). According to Munawir (2005: 72) the most commonly used ratio is the Current Ratio because this ratio serves to show the level of safety (margin of safety) to meet its obligations. According to Lukman (2018: 53) the company should have a current ratio of at least 1 (one) time, if the number owned is less than 1 (one) it will indicate that the company's condition is not good so the company must cover its obligations with fixed assets.

According to Kamsir (2014: 113) the solvency ratio serves to measure the extent to which the company's assets can finance its debt, by knowing the solvency ratio can make it easier for companies to assess the company's ability to obligations to other parties assess the company's ability to meet its obligations that are fixed, knowing balance between assets, especially fixed assets and capital, as well as a basis for decision making for future sources of funds. Debt to total assets is useful to measure how the assets used can guarantee liabilities owned, besides that debt to total assets also serves to assess the extent to which debt affects the management of assets. 
Effect of Profitability (Net Profit Margin) against disclosure of CSR

Companies with a large profit tends to be the center of attention so that the stakeholders whishes the company's to do transparency (Hasnia \& Rofingatun, 2017). Thus the company will disclose CSR as an effort to meet the wishes of the stakeholders. Companies with a net profit margin high tend to perform wider CSR with the aim to improve their company image and show that the company is not only the profits alone but also have social and environmental concerns.

Effect of Liquidity (Current Ratio) on CSR Disclosures

Current ratio better is about $2: 1$, company with a current ratio of good will increasingly carry out CSR this happens because the company wanted to show creditors that the company can meet its obligation at any time.

\section{Effect of Solvency (Debt to Total Assets) on CSR Disclosures}

Kamsir (2014: 156) companies with high debt to total assets show that funding sourced from debt will be so much that it will be increasingly difficult for companies to get loans because it is feared that the company is unable to cover its debt with existing assets. The company will show a good debt to total assets so that the lender is willing to lend to the company. There the company will do a lot of CSR disclosure in order to convince creditors even though they still have obligations, but the company is still able to prepare funds to carry out CSR.

\section{Hypothesis}

Based on literature review and frame of mind, the hypotheses proposed in this study can be formulated as follows: Profitability, Liquidity, and Solvency simultaneously affect the company's CSR disclosure in the Sri-Kehati Index 2015-2018. Profitability partially influences the company's CSR disclosure in the 2015-2018 Sri-Kehati Index. Liquidity partially influences CSR disclosure in the 2015-2018 Sri-Kehati Index. Solvency partially influences CSR disclosure in the 2015-2018 Sri-Kehati Index.

\section{METHODS}

This research uses quantitative methods. Mechanical sampling the tech nique used is purposive sampling. Following are the criteria selection

Table 1 Criteria Sample

\begin{tabular}{lll}
\hline No & \multicolumn{1}{c}{ Criteria } & \multicolumn{1}{c}{ Company's } \\
\hline 1 & $\begin{array}{l}\text { Company that are consistently listed in the Sri-Kehati Index } \\
\text { for 2015-2018 }\end{array}$ & 22 \\
2 & $\begin{array}{l}\text { Companies that are inconsistent in publishing financial } \\
\text { report and annual report in the Sri-Kehati Index for 2015- }\end{array}$ & 2 \\
& 2018 & \\
3 & Financial companies in the Sri-kehati Index for 2015-2018 & $(5)$ \\
& Total samples in a year & 15 \\
& Research year (2015-2018) & 4 \\
& Total samples & 60 \\
\hline
\end{tabular}

Source: data that has been processed by the author (2020)

The data analysis method used in this study is panel data regression, analysis using Eviews 10 with panel data regression model equation in this study are:

$$
Y=\alpha+\beta_{1} X_{1} \text { it }+\beta_{2} X_{2} i t+\beta_{3} X_{3} i t+\varepsilon
$$


Where:

$\mathrm{Y}=\mathrm{CSR}$ disclosure in the t-year company

$\beta_{1}, \beta_{2}, \beta_{3}=$ regression coefficients of each variable

$\alpha=$ constant

$\mathrm{t}=$ time $\mathrm{i}$ = company

$\varepsilon=$ item error

$X_{1}$ it $=$ Profitability in the company i year $\mathrm{t}$

$\mathrm{X}_{2}$ it $=$ Liquidity at company $\mathrm{i}$ year $\mathrm{t}$

$\mathrm{X}_{3}$ it $=$ Solvency in company $\mathrm{i}$ year $\mathrm{t}$

\section{RESULTS AND DISCUSSION \\ Descriptive Statistical Analysis}

Table 2. Descriptive Statistic

\begin{tabular}{lcccc}
\hline & CSR & NPM & CR & DAR \\
\hline Mean & 0.282185 & 0.156235 & 1.696362 & 0.522865 \\
Median & 0.269200 & 0.097350 & 1.515400 & 0.512850 \\
Maximum & 0.527400 & 1.794700 & 4.657700 & 0.792800 \\
Minimum & 0.197800 & 0.012300 & 0.380000 & 0.157100 \\
Std. Dev. & 0.052306 & 0.240320 & 0.942337 & 0.168601 \\
\hline
\end{tabular}

Source: Eviews output, 2020

In the table it can be seen that the average value of each variable, both the dependent variable and independent, have a greater value in the comparative standard deviation. This shows that the companies in the Sri-Kehati Index that were sampled in the study had data that did not vary.

\section{Classic Assumption Test}

According to (Basuki \& Prawoto, 2016) not all classic assumption tests need to be done, because in this study using more than one independent variable and there is data that is a cross section data, it is mandatory to test only heterokedasticity test and multicollinearity test, therefore normality test and autocorrelation does not need to be done.

\section{Multicollinearity Test}

Table 3. Multicollinearity Test

\begin{tabular}{cccc}
\hline & NPM & CR & DAR \\
\hline \hline NPM & 1.000000 & 0.052246 & -0.119275 \\
CR & 0.052246 & 1.000000 & -0.650321 \\
DAR & -0.119275 & -0.650321 & 1.000000 \\
\hline \multicolumn{4}{c}{ Source: Eviews output, 2020 }
\end{tabular}

Based on the multicolloniality test results in the table, there is no multicolliniality because the results obtained are less than 0.95 . 
JASa (Jurnal Akuntansi, Audit dan Sistem Informasi Akuntansi)

Vol. 4 No. 3/ December 2020

ISSN 2550-0732 print / ISSN 2655-8319 online

\section{Heterokedasticity Test}

Table 4. Heterokedasticity Test

\begin{tabular}{crrrr}
\hline Variable & Coefficient & Std. Error & t-Statistic & Prob. \\
\hline \hline C & -5.990396 & 0.968521 & -6.185096 & 0.0000 \\
NPM & -0.404234 & 0.307937 & -1.312716 & 0.1946 \\
CR & 0.247277 & 0.658517 & 0.375506 & 0.7087 \\
DAR & -0.131143 & 0.948203 & -0.138307 & 0.8905 \\
\hline
\end{tabular}

Source: Eviews output, 2020

Based on the table, it can be seen that the probability of each variable is greater than alpha, namely 0.1946 for NPM, 0.7078 for CR, and 0.8905 for
DAR so that it can be concluded that no heterokedasticity was found, so the heterokedastity test can be fulfilled.

\section{Selection Of Panel Data Regression Model Chow Test}

Table 5. Chow Test

\begin{tabular}{lrrr}
\hline Effects Test & Statistic & d.f. & Prob. \\
\hline \hline Cross-section F & 5.883456 & $(14,42)$ & 0.0000 \\
Cross-section Chi-square & 65.134705 & 14 & 0.0000 \\
\hline
\end{tabular}

Source: Eviews output, 2020

Based on this table shows that the probability (cross section chi-square) $\leq$ 0.05 then $\mathrm{H}_{0}$ is rejected and

\section{Hausman Test}

Table 6. Hausman Test

\begin{tabular}{lrrr}
\hline Test Summary & $\begin{array}{r}\text { Chi-Sq. } \\
\text { Statistic }\end{array}$ & Chi-Sq. d.f. & Prob. \\
\hline \hline Cross-section random & 9.307506 & 3 & 0.0255 \\
\hline
\end{tabular}

Source: Eviews output, 2020

The table shows that the value of
a random cross section is 0.0255 . Because the probability (cross section random) $>0.05$, then $\mathrm{H}_{0}$ is received and $\mathrm{H}_{1}$ rejected or preferably panel data regression using a fixed effect.

$\mathrm{H}_{1}$ accepted that panel data regression models should use fixed effect. 


\section{Regression Data Panel Using Fixed \\ Effect Model \\ Fixed Effect Test Results}

Table 7. Fixed Effect Model

\begin{tabular}{crrrr}
\hline Variable & Coefficient & Std. Error & t-Statistic & Prob. \\
\hline \hline C & -0.951348 & 0.125279 & -7.593809 & 0.0000 \\
NPM & 0.071334 & 0.023763 & 3.001857 & 0.0045 \\
CR & 0.158780 & 0.074602 & 2.128352 & 0.0392 \\
DAR & 0.329860 & 0.162064 & 2.035367 & 0.0482 \\
\hline \multicolumn{5}{c}{ Source: Eviews output, 2020 }
\end{tabular}

Based on the panel data regression analysis table, the following equation is obtained:

$\mathrm{Y}=-0,951348+0.071334$ (NPM) $+0.158789(\mathrm{CR})+0.329860(\mathrm{DAR})$

Where

\section{F Test (Simultaneous Testing)}

Table 8. F Test

\begin{tabular}{lllr} 
R-squared & 0.665176 & Mean dependent var & 1.286324 \\
\hline Adjusted R-squared & 0.529652 & S.D. dependent var & 0.170174 \\
& & & - \\
S.E. of regression & 0.116709 & Akaike info criterion & 1.214948 \\
& & & - \\
Sum squared resid & 0.572078 & Schwarz criterion & 0.586645 \\
& & & - \\
Log likelihood & 54.44844 & Hannan-Quinn criter. & 0.969184 \\
F-statistic & 4.908185 & Durbin-Watson stat & 2.370782 \\
Prob(F-statistic) & 0.000013 & & \\
\hline
\end{tabular}

Source: Eviews output, 2020

The table is based on the probability of which is owned by 0.000013 which is less than 0.05 , then

$\mathrm{H}_{0}$ is rejected and $\mathrm{H}_{1}$ accepted that changes in the independent variables affect the variable dependent.

\section{T Test (Partial Testing)}

Table 9. T Test

\begin{tabular}{crrrr}
\hline Variable & Coefficient & Std. Error & t-Statistic & Prob. \\
\hline \hline C & -0.951348 & 0.125279 & -7.593809 & 0.0000 \\
NPM & 0.071334 & 0.023763 & 3.001857 & 0.0045 \\
CR & 0.158780 & 0.074602 & 2.128352 & 0.0392 \\
DAR & 0.329860 & 0.162064 & 2.035367 & 0.0482 \\
\hline
\end{tabular}

Source: Eviews output, 2020 
Based on the table the probability is owned: NPM has a probability of 0.0045 so that it is smaller than 0.05, then NPM affects the CSR disclosure. CR has a probability of 0.0392 and the value is smaller than 0.05 so that CR affects the CSR disclosure. Whereas for DAR it has a probability value of 0.0482 where the number is smaller than 0.05 so DAR has an effect on CSR disclosure.

\section{Coefficient Determination Test}

The coefficient of determination is used to measure the ability of the model to explain the variation of independent variables in influencing the dependent variable expressed in percentage. In the table the value of $\mathrm{R}$ 2indicated by the value $R$ squared, then the coefficient of determination will be obtained as follows

$R^{2}=R^{2} \times 100 \%$

$R^{2}=0.6651 \times 100 \%$

$\mathrm{R}^{2}=66.51 \%$

Thus it can be concluded that the ability of independent variables namely profitability proxy by NPM, liquidity proxy by $\mathrm{CR}$, and solvency proxy by DAR are able to influence the dependent variable is CSR disclosure of $66.51 \%$ while the remaining $35.49 \%$ is explained by variables other than this research.

\section{Effect of Profitability (Net Profit Margin) on CSR Disclosures}

The probability value of the NPM itself is 0,0045 where the value is smaller than the significance value of 0.05 so that $\mathrm{H}_{01}=$ profitability has no partial effect on corporate social responsibility disclosure rejected and $\mathrm{H}_{\text {at }}$ is accepted. Company with the net profit margin is high tend to perform CSR increasingly widespread with the aim to improve their company image and show that the company is not only the profits alone but also has a concern for the environment and social means that in the event of changes in the value of NPM then CSR is happening does not always adjust to changes in NPM, it could be that when the value of NPM rises the disclosure will be even less.

\section{Effect of Liquidity (Current Ratio) on CSR Disclosures}

The probability value of $C R$ itself is 0.0392 where the value is less than the significance value of 0.05 so that $\mathrm{H}_{02}=$ liquidity has no partial effect on corporate social responsibility disclosure y rejected and $\mathrm{H}_{\mathrm{a} 2}$ is accepted. Company with a current ratio of good will increasingly carry out CSR this happens because the company wanted to show creditors that the company can meet its obligations at any time (Wasito, Herwiyanti, \& Kusumastati, 2016) means that in this study stated that the CR effect on disclosure CSR or the higher the CR CSR disclosures made are also higher.

\section{Effect of Solvency (Debt to total assets) on CSR Disclosures}

A probability value of DAR itself is 0.0482 where the value is smaller than the significance value of 0.05 so that $\mathrm{H}_{03}=$ solvency no partial effect on the disclosure of corporate social responsibility in rejected and $\mathrm{H}_{\mathrm{a} 3}$ accepted. There the company will do a lot of CSR disclosures in order to convince creditors even though they still have obligations but the company is still able to prepare funds to carry out CSR. Thus debt to total assets affect CSR disclosure.

\section{CONCLUSION}

Based on the results of simultaneous hypothesis testing, the independent variables, namely profitability (net profit margin), liquidity (current ratio), and solvency (debt to total asset ratio) jointly influence the disclosure of CSR in companies listed in the Sri-Kehati index for the 2015 period -2018. The ability of independent variables namely profitability proxy by 
NPM, liquidity proxy by $\mathrm{CR}$, and solvency proxy by DAR are able to influence independent variable CSR disclosure of $66.51 \%$ while the remaining $34.49 \%$ is explained by other variables outside this study. Based on partial test results. Profitability which is proxy by Net Profit Margin affects the disclosure of CSR in companies listed in

\section{REFERENCES}

Basuki, A. T., \& Prawoto, N. (2016). Analisis Regresi dalam Penelitian Ekonomi dan Bisnis. Jakarta: Raja Grafindo.

D, H. (2018, Juli 13). SWA. Retrieved from http://swa.co.id/businesschampions/companiea/indekssri-kehati-seimbangkan-aspekbisnis-dan-lingkungan

D, S. R. (2016, Juli 21). CNN Indonesia. Retrieved from https://m.cnnindonesia.com/nasi onal/20160721074144-20146030/riset-temukan-kualitascsr-perusahaan-indonesiarendah

Hasnia, \& Rofingatun, S. (2017). Pengaruh Profitabilitas, Likuiditas, Growth, dan Media Exposure Terhadap Pengungkapan Tanggung Jawab Sosial Perusahaan. Jurnal Akuntansi \& Keuangan Daerah Volume 12 Nomor 1, 58.

Kamsir, S. M. (2014). Analisis Laporan Keuangan, Edisi Satu. Cetakan the Sri-Kehati index for 2015-2018. Liquidity that is proxy by Current Ratio affects CSR disclosure in companies listed in the Sri-Kehati index for 2015-2018. Solvency which is proxy by Debt to Total Assets affects the disclosure of CSR in companies listed in the Sri-Kehati index for 2015-2018.

Ketujuh. Jakarta: PT Raja Grafindo Persada.

Lukman, M. (2018). Keuangan Korporat Teori dan Praktik di Indonesia. Jakarta: Bumi Aksara.

Mardikanto, T. (2014). Corporate Social Responsibility (Tanggungjawab Sosial Korporasi). Bandung: Alfabeta.

Maulani, S. S., \& Mudjiyanti, R. (2017). Pengaruh Likuiditas dan Profitabilitas Terhadap Pengungkapan Corporate Social Responsibiity pada Perusahaan Terdaftar di bursa Efek Indonesia. Jurnal Akuntansi dan Sistem Teknologi Informasi, 344.

Munawir, D. S. (2005). Analisa Laporan Keuangan Edisi Keempat. Yogyakarta: Liberty.

Wasito, G. A., Herwiyanti, E., \& Kusumastati, W. W. (2016). Pengaruh Corporate Governance, Profitabilitas, Likuiditas, dan Solvabilitas terhadap Corporate Social Responsibility Disclosure. Jurnal Bisnis dan Akuntansi. 